\title{
Discrimination in California Housing: The Need for Additional Legislation
}

\author{
Marshall Kaplan*
}

But if some Americans, because of their color, race, religion, or national origin have no choice but to grow up and live in conditions of squalor and in rigidly confined areas, then all of America suffers. ${ }^{1}$

In 1959, the Commission found that 'housing ... seems to be the one commodity in the American market that is not freely available on equal terms to everyone who can afford to pay.' Today, two years later, the situation is not noticeably better. ${ }^{2}$

\section{I}

\section{BACKGROUND-EVOLUTION OF A POLICY}

Immediately after the adoption of the civil rights amendments, Congress enacted a series of acts pertaining to civil rights. ${ }^{3}$ These statutes prohibited racial discrimination in certain places of public accommodation, including inns, conveyances, and places of amusement. Rather than construe the fourteenth amendment as providing Congress with plenary power to regulate private actions (enumerated in the Civil Rights Acts), the Supreme Court, in the Civil Rights Cases, ${ }^{4}$ held that the fourteenth amendment prohibited only official state action, not individual private violation of civil rights, and that Congress could enact only corrective and remedial, not positive and general legislation.

Generally, the precedents set down in the Civil Rights Cases have continued to be observed by the judiciary. ${ }^{5}$ But, not surprisingly, the judicial Problems.

* Report Coordinator, State of California Governor's Advisory Commission on Housing

1 Report of the United States Commsston on Civil Rights 332 (1959).

24 Report of the United States Commission on Crvil Rtghts (Housing) 1 (1961).

3 Civil Rights Act of 1866, ch. 31, 14 Stat. 27; Enforcement Act of 1870, ch. 114, 16 Stat. 140; Civil Rights Act of 1875, ch. 114, 18 Stat. 335.

4109 U.S. 3 (1883).

5 The growing list of discriminatory actions that constitute a violation of the fourteenth amendment indicates both the expanding role of government and the evolution of the concept of "state action." E.g., Racial Zoning: Buchanon v. Warley, 245 U.S. 60 (1917); Shelley v. Kraemer, 334 U.S. 1 (1948); Public Housing: Burks v. Housing Authority, 120 Cal. App. 2d 1, 260 P.2d 668 (1953), cert. denied, 347 U.S. 974 (1954); Schools: Brown v. Board of Education, 347 U.S. 483 (1954) ; Bolling v. Sharp, 347 U.S. 497 (1954).

In Railway Mail Ass'n v. Corsi, 326 U.S. 88 (1945), the use of the fourteenth amendment by the discriminator as a defense was denied. The Court felt that to utilize this amendment to protect one who discriminates would contravene its spirit.

The degree and effect of government involvement appears critical throughout all of these cases. It can be expected, however, that "state action" will continue to encompass more activities. See, e.g., Burton v. Wilmington Parking Authority, 365 U.S. 715 (1961). 
veto exercised by the Court in 1883 , has proved to be a catalyst in producing antidiscrimination legislation in various states. ${ }^{\circ}$

As early as 1872 , the State of California attached penal sanctions to innkeepers and carriers who evidenced discriminatory practices. ${ }^{7}$ Substantive legislation pertaining to public accommodations, however, was not enacted until $1893 .{ }^{8}$ This first attempt at a comprehensive statement relative to discriminatory actions was expanded upon four years later. ${ }^{\circ}$ But definitive changes awaited the 1959 legislative session. Prior to 1959, the basic public policy of the State of California, with respect to discriminatory activities, was reflected in the then sections 51 and 53 of the Civil Code: ${ }^{10}$

All Citizens within the jurisdiction of this state are entitled to the full and equal accommodations, advantages, facilities and privileges of inns, restaurants, hotels, eating houses, places where ice cream or soft drinks of any kind are sold for consumption on the premises, barber shops, bath houses, theatres, skating rinks, public conveyances and all other places of public accommodation or amusement, subject only to the conditions and limitations estabhshed by law and applicable alike to all citizens. ${ }^{11}$

It is unlawful for any corporation, person, or association, or the proprietor, lessee, or the agents of either, of any opera house, theatre, melodeon, museum, circus, caravan, race course, fair, or other place of public amusement or entertainment, to refuse admittance to any person over the age of twenty-one years, who presents a ticket of admission acquired by purchase, or who tenders the price thereof for such ticket, and who demands admission to such place. Any person under the influence of liquor, or who is guilty of boistrous conduct, or any person of lewd or immoral character, may be excluded from any such place of amusement. ${ }^{22}$

It is apparent that "the greatest point of contention arising under this statute was in applying the phrase 'places of public accommodation or amusement' to particular factual situations." ${ }^{13}$ After careful analysis of

${ }^{6}$ See appendix for a comprehensive list of state legislation relating to discrimination in housing.

7 See Cat. Pen. Code $\$ 365$.

8 Cal. Stat. 1893, ch. 185, at 220.

9 Cal. Stat. 1897 , ch. 108, at 137.

10 The 1893 and 1897 statutes were codified in Cal. Stat. 1905, ch. 413, §§ 1-4, at 553. Minor amendments followed in 1919 and 1923.

11 It is evident that the legislature intended, through Cax. Crv. CoDE $\$ \$ 51-54$, to implement the same policy expressed in the federal Civil Rights Act of 1875 , declared unconstitutional in the Civil Rights Cases. Section 1 of that federal act declared:

That all persons within the jurisdiction of the United States shall be entitled to the full and equal enjoyment of the accomodations, advantages, facilities, and privileges of inns, public conveyances on land or water, theaters and other places of public amusement; subject only to the conditions and limitations establisbed by law, and applicable alike to citizens of every race and color, regardless of any previous condition of servitude.

12 CAL. Crv. CODE $\$ \S 52$ and 54 provided remedies for violations of $\$ \S 51$ and 53 , respectively.

13 Brief for Appellant (prepared by Marshall W. Krause, ACLU), p. 6, Burks v. Poppy Constr. Co., 57 Cal. 2d 503, 370 P.2d 313, 20 Cal. Rptr. 609 (1962). 
specific cases emanating from sections $51-54$, Horowit ${ }^{14}$ described the statutes as referring to fact situations that are nongratuitous, noncontinuous, nonpersonal, and nonsocial. Despite debate over coverage, rarely was the validity of the proscription disputed, and when it was the courts held the acts constitutional. .5 $^{15}$

Since sections $51-54$ were significantly changed in 1959 , a lengthy discussion of them at this time would serve no useful purpose. ${ }^{16}$ Nevertheless, certain ramifications that have a bearing on future legislation are implicit in the early civil rights statutes and cases concerning those acts.

In James v. Marinship Corp. ${ }^{17}$ the California Supreme Court declared, in effect, that the rights protected within the framework of the public accommodation statutes had existed at common law. Therefore, a nonstatutory cause of action will lie even where "private rather than public action is involved," provided that such action is contrary to public policy. ${ }^{18} \mathrm{Al}-$ though the James case involved discrimination against Negroes by a labor union, the fact remains that the court saw fit to extend the umbrella of state regnlation over an essentially private relationship by enjoining the employer from assisting the discriminatory labor practices.

Taking James and the similar case of Williams v. International Bhd. of Boilermakers ${ }^{19}$ together, it seems that the state, in order to protect one of the parties from discriminatory acts, may regnlate private relationships in

14 Horowitz, The 1959 Equal Rights in "Business Establishments" Statute-A Problem in Statutory Application, 33 So. CAT. L. REv. 260, 288 (1960).

15 Western Turf Ass'n v. Greenberg, 204 U.S. 359 (1907); see Orloff v. Los Angeles Turf Club Inc., 36 Cal. 2d 734, 227 P.2d 449 (1951); Piluso v. Spenser, 36 Cal. App. 416, 172 Pac. 412 (1918).

${ }^{16}$ For such an analysis see Klein, The California Equal Rights Statutes in Practice, 10 StaN. L. REv. 253, 257 (1958); Horowitz, The 1959 California Equal Rights in "Business Establishments" Statute-A Problem in Statutory Application, 33 So. CAL. L. REv. 260, 277 (1960).

Perhaps it might be wise to distinguish between the term "civil rights" and "equal rights" in order to vividly portray the increased limitations placed on discriminatory activities originally thought "safe" from government restrictions. Commenting on this duality, Klein states, "In fact, these statutes [\$§ 51-54 before amendments in 1959] are not concerned primarily with 'civil' or 'public' rights at all, in the sense of rights pertaining to the individual's relationship to the state, but rather with the protection of equal rights with respect to facilities and services offered to the public by private persons. The rights protected involve the individual's relationship to other individuals." Id. at 255 . Klein's comments apply equally well to the legislation enacted in 1959.

1725 Cal. 2d 721, 155 P.2d 329 (1944).

$18 \mathrm{Id}$. at 740, $155 \mathrm{P} .2 \mathrm{~d}$ at 340 . See Williams v. International Bhd. of Boilermakers, $27 \mathrm{Cal}$. 2d 586, 165 P.2d 903 (1946). Justice Frankfurter, concurring in Railway Mail Ass'n v. Corsi, 326 U.S. 88, 97 (1945), provided additional force to the reasoning of the James and Williams cases. The Justice also effectively illuminated the reasons why a defendant may not use the fourteenth amendment as a shield against state action aimed at stamping out racial discrimination. Id. at 98.

1927 Cal. 2d 586, 165 P.2d 903 (1946). 
the following situations: (a) when an individual may be deprived of a substantive right (e.g., the right to work), and (b) when the discriminator has a monopoly over an essential commodity. In essence, the nature of the right denied, the type of relationship between the parties, and the degree to which the activities of the discriminator assume the image of a public activity were probably the factors considered by the courts as criteria justifying state regulation.

While prior to 1959 , sections 51-54 of the Civil Code provided the basic framework within which the state protected individuals against infringement of civil rights, extensive legislation was enacted which prohibited discrimination in relationships not specifically covered by the phrase "public accommodations."

Ostensibly, then, these legislative proscriptions, complemented by several court decisions, have established the fact that the public policy of the State of California is against discrimination. Without precise statutory definition, however, the extent to which courts may restrict discrimination emanating from private relationships is debatable. Referring to the James case, the attorney general has stated: "What had hitherto been regarded as a rule of public policy affecting only government and public services enterprises, has become to soine extent, not yet clearly delineated, a rule of conduct affecting private individuals and organizations."20 Since an omnibus civil rights bill has not yet been passed by the legislature, the courts must continue to fill in the interstices.

II

EVOLUTION OF CIVII RIGHTS: THE HAWKINS AND UNRUH ACTS

Two significant statutes expanding the scope of existing policy toward discrimination in housing were enacted during the 1959 legislative session. In effect, these statutes prohibit discrimination on the grounds of race, color, religion, ancestry, or national origin by:

1. Persons selling or renting "publicly assisted lousing" (the Hawkins Act) $;^{21}$ and

2. "All business establisliments of every kind whatsoever" (the Unruh Act). ${ }^{22}$

The Hawkins Act, in general, prolibits discriminatory activities associated with the sale, leasing, or rental of any housing accommodations that

209 Ops. Cal. Att'y Gen. 271, 274 (1947). (Emphasis added.)

21 Cad. Heatth \& SaEety CoDE $\$ \$ 35700-41$, specifically $\$ \$ 35710(3), 35720$.

$22 \mathrm{CAL}$. Crv. CoDE $\$ \S 51-52$. A third similar provision was aimed at employers of five persons or more. CAL. LAB. CoDE $\$ \S 1410-32$. 
are: exempt from state or local taxes, ${ }^{23}$ or located in a multiple dwelling ${ }^{24}$ financed in certain respects by a loan secured by the state or federal government; or constructed on land acquired by the state or local government through condemnation proceedings, ${ }^{25}$ or sold below cost by the state or any of its political subdivisions. In addition, coverage extends to housing accommodations that are financed in certain respects by loans secured by the state or federal government and offered for sale by one who owns or controls the sale of five or more umits located on contiguous land (essentially, tract developments).

Even a cursory examination reveals the inescapable fact that a considerable number of dwelling units are outside the scope of the Hawkins Act. ${ }^{26}$ Moreover, unlike statutes in other states, ${ }^{27}$ the act effectively restricts the discriminatory activities of only the original developer of tract housing. ${ }^{28}$ Once a tract has been subdivided into individually owned lots, the present statute, for all practical purposes, is not effective even though an outstanding loan or mortgage on a unit remains secured by a govermnental agency. ${ }^{29}$

As interpreted by the courts, in many instances the Unruh Act extends prohibitions against discriminatory activities to transactions involving nonpublicly assisted units as well as to individual publicly assisted dwellings. It must be emphasized, however, that the Unruh Act remains essentially an enactment regulating the activities of business establishments. The current act provides:

All persons within the jurisdiction of this State are free and equal, and no matter what their race, color, religion, ancestry, or national origin are entitled to the full and equal accommodations, advantages, facilities, privileges, or services in all business establishments of every kind whatsoever. ${ }^{30}$

23 Exception-an owner who enjoys any type of tax exemption solely because of his veteran's status.

24 A "multiple dwelling" is defined as a residence for three or more families living independently of one another. CAX. HEALTH \& SAFETY CODE $\$ 35710(6)$.

25 Before amendment in 1961, the statute exempted property acquired by the Department of Veterans Affairs under the Veterans' Farm and Home Purchase Act of 1943 (Cal. Vet.).

26 It is probable that this figure approximates $80 \%$.

27 The Massachusetts statute reads as follows: "Contiguously located housing" ineans ... housing which is offered for sale, lease, or rental and which at any time was one of ten or more lots of a tract whose plan has been submitted to a planning board as required by the subdivision control law. ..." MASs. GEN. LAws ANN. ch. 151B, \& 1 (1959). (Emphasis added.)

28 It might be possible for a subdivider himself to circumvent the law by "selling off" strategically located units first, thus in effect negating the restrictions applicable to units located on contiguous land.

29 Implicit exemptions of single family dwelling units which are nonpublicly assisted or publicly insured but below the five unit minimum would seem to mitigate the opportunity to "open up" standard older city units.

30 CaL. Civ. Code $\$ 51$. (Emphasis added.) The 1961 amendment substituted "person" for "citizen." The 1959 enactment repealed $\$ \S 53$ and 54 and rewrote $\$ \$ 1$ and 52. In 1961, a new $\S 53$ was added which prohibits discrimination in real property instruments. 
Recent decisions by the California Supreme Court have upheld the constitutionality and clarified the coverage of both acts. Referring to the provisions of the Unruh Act, the court, in Burks v. Poppy Constr. Co. ${ }^{31}$ held that the act is valid and applies to real estate transactions, and stated:

Discrimination on the basis of race or color is contrary to the public policy of the United States and of this state. . . The legislature in the exercise of the police power ${ }^{32}$ may in appropriate circumstances prohibit private persons or organizations from violating this policy.... [T] here is no valid reason why the extension of the prohibition against discrimination to 'all business establishments,' including those dealing with housing, would be violative of due process. ... Under the police power reasonable restrictions may be placed upon the conduct of any business and the use of any property, ... and the restriction herein iniposed in furtherance of the policy against discrimination is reasonable.

The court also denied the defendant's contention that the Hawkins Act was unconstitutional due to its retroactive nature. "The Hawkins Act imposes sanctions upon conduct occurring after the effective date of the statute, and it does not operate retroactively merely because it may apply in some instances to lrousing which was receiving public assistance when the statute was enacted." 33 Moreover, defendant's theory that the statute contravened the equal protection clause of the fourteenth amendment was not acceptable to the court. On the contrary, the extension of the prohibition against discriminatory action to publicly assisted private housing was interpreted as a reasonable enactment-a further step in the application of an already existing policy. ${ }^{34}$

Quite significantly, the court also held that although the Hawkins Act related specifically to housing, this fact did not pre-empt the Unruh Act from regulating discriminatory practices with respect to housing as well. But just how far the act will affect the housing market is unclear.

Given the fact of the broad language of the Unruh Act, the court will have to determine in each specific situation whether the act reaches out to enbrace the discriminator. It appears that the statute may invite litigation in situations where the nature of the activities pertaining to the selling, renting, or leasing of units cannot clearly be defined as a business. Conversely, the aggrieved party may hesitate to proceed with an action because

3157 Cal. 2d 503, 511-12, 370 P.2d 313, 317, 20 Cal. Rptr. 609, 613 (1962).

32 (Footnote added.) The constitutionality of legislation regulating business activities and nonpublicly assisted dwelling units is generally based on an extension of the police power. See, e.g., Massachusetts Comm'n Against Discrimination v. Colangelo, 182 N.E.2d 595 (Mass. 1962). The fourteenth amendment (equal protection clause), on the other hand, is utilized to support restrictions on the sale, lease, or rental of publicly assisted units.

$3357 \mathrm{Cal} .2 \mathrm{~d}$ at 515,370 P.2d at 319, $20 \mathrm{Cal}$. Rptr. at 615.

34 See also Hudson v. Nixon, 57 Cal.2d 523, 370 P.2d 324, 20 Cal. Rptr. 620 (1962). 
of doubt as to the meaning and application of "business establishments."

In Lee v. O'Hara, ${ }^{36}$ decided the same day as the Burks case, the supreme court decided that the office of a real estate broker was a "business establishment" and that brokers who have authority to transact business with anyone who is ready, willing, and able to deal are covered by the act. Nevertheless, continuing difficulties in establishing the precise legal relationship and responsibilities of both broker and seller appear to negate effective applications of the act. Ostensibly, given the interpretation in the Lee case, a broker would not escape liability by claiming that as an agent he may discriminate so long as his principal is privileged to do so. But language in Vargas v. Hampson ${ }^{37}$ casts doubt on the effectiveness of restrictions placed on the broker. The court there said:

In some circumstances, of course, both a broker and an owner may be guilty of discrimination, but a broker who in good faith does all within his power to serve a member of a racial minority is not liable if the broker's failure to complete the transaction is due solely to the owner's refusal to sell because of the buyer's race or color.

Given the close and continuing relationship existing between broker and seller (or lessor), it would normally be quite difficult for the aggrieved party to prove which one-broker or seller-originated the act of discrimination. The problem becomes critical in situations where the umit in question does not fall within the purview of the Hawkins Act or other statutes. In such a situation, the owner would have very little reason, unless motivated by egalitarian principles, to resist a "rational suggestion" by a broker that he agree to withhold the dwelling in question froin inembers of a minority group..$^{38}$ That the broker is often the catalyst in this relationship seems apparent, for "in the housing area ... a reputation for discrimination may even enhance the reputation of a broker or builder. . ...39

Creation of useful standards of evaluating "behavior" in the broker-

35 Horowitz suggests that the term "business establishments" includes "those private individuals and privately-owned entities which offer to enter into nongratuitous relationships with other persons, those relationships being generally (1) in the form of extending 'accommodations, advantages, facilities, privileges, or services,' and (2) of a relatively noncontinuous, nonpersonal, nonsocial sort." Horowitz, The 1959 California Equal Rights in "Business Establishments" Statute-A Problem in Statutory Application, 33 So. CAL. L. REv. 260, 289 (1960).

3657 Cal. 2d 517, 370 P.2d 321, 20 Cal. Rptr. 617 (1962).

3757 Cal. 2d 519, 522, 370 P.2d 322, 324, 20 Cal. Rptr. 618, 620 (1962).

38 The court inferred in the Burks case that an overt or affirmative act by the principal is necessary before a broker could utilize the desire of the principal as a defense. Assuming a willing owner, such an overt act would not be difficult to produce. Definition of an overt act would probably vary depending on an evaluation by the court of facts in each case.

39 Bamberger \& Lewin, The Right to Equal Treatnent: Administrative Enforcement of Antidiscrintination Legislation, 74 HARV. L. Rev. 526, 541 (1961). 
seller or broker-buyer relationships is concededly a difficult task. Moreover, the courts have not, as yet, had extensive opportunities to interpret the scope of the changes in the agent-principal relationship implied by the Unruh Act. But, while it is not clear, it appears that the existing case law permits a broker to accept a histing that is prima facie not available to particular individuals, because of race, color, etc., as long as the full range of services is offered to all buyers. Obviously, this result would negate both the principle and spirit of the act. ${ }^{40}$ If the broker is aware at the time of listing that the seller will not complete the transaction, should the buyer be a Negro, then the broker should be held liable under the act. Mere provision of services, with concurrent awareness that a sale or rental is impossible, should not absolve the broker.

Neither the Hawkins nor the Unruh Act provides an administrative mechanisin for implementing the stated objectives explicit in each. The only remedial recourse for an aggrieved party is a civil action. Individuals who violate the Unruh Act are liable, under section 52 of the Civil Code, for actual damages in addition to a $\$ 250$ statutory penalty payable to the plaintiff. Under the Hawkins Act the person aggrieved may recover money damages of not less than $\$ 500 .^{41}$ In either case, compensatory damages are difficult to calculate and often provide an inadequate substitute for the desired hoine. ${ }^{42}$

Without a temporary restraining order or injunction, the dwelling unit might be sold, rented, or leased during the course of the civil proceeding. Basically, two methods of preserving the property for the plaintiff are available. First, plaintiff may file a lis pendens, ${ }^{43}$ a notification to potential buyers that rights to the property in question are in litigation and that if they purchase the property they are in danger of being bound by an adverse judgment. The second and more clearly satisfactory alternative is for the plaintiff to seek injunctive relief during the prelininary stages of the action. The Hawkins Act expressly provides for "a right of action ... for restraint of such violation and for other equitable remedies including ... affirmative relief. ..." ${ }^{\prime 4}$ Plaintiff may proceed in a similar manner against alleged vio-

40 Obviously, the Unruh Act conferred certain rights on the citizen, but it also established correlative duties. Upon meeting lawful conditions imposed by the broker, the citizen has a positive right in personam to the full and equal services of the broker in his business establishment; and the broker has a positive duty to provide these services. See Comment, The Unruh Civil Rights Act As Applied to Real Estate Brokers, 13 Hastings L.J. 120 (1961). 41 Cat. Heatth \& Safety Code $\$ 35730$.

42 Given the expenses emanating from a lengthy trial, the doubt as to the outcome, inmediate need for housing, and the difficulty in calculating damages, many victims of discrimination may not (or cannot) imitiate court action. See Bamberger \& Lewin, supra note 39, at 526.

43 Cat. Code CTv. Proc. $\$ 409$.

44 CaL. Health \& Safety Code $\$ 35730$. 
lators of the Unruh Act. The supreme court has held that, although the right to procure equitable remedies is not spelled out in the act, injunctive relief is available. ${ }^{45}$

To date, however, it appears that the hardship and annoyance associated with seeking redress through the judicial process have discouraged individuals from enforcing their rights, thus negating the effectiveness of the statutes.

An individual [discriminated against], who has a good cause of action must hire a lawyer, involve himself in litigation which is consuming both in terms of time and money; and be willing to wait months, or even years, for a determination. ... Furthermore, there is the problem of preserving the property which the plaintiff desires to have. ${ }^{46}$

The Hawkins and Unruh statutes represent significant statements of legislative policy with regard to discriminatory practices in publicly assisted housing and, in certain situations, in dwelling units lacking in public assistance. In effect, California has established certain policy parameters with respect to discrimination in the housing market, but, as inferred above, both present statutory law and the interpretive court decisions clearly suggest the need for additional legislation if practice is to become one with policy.

\section{III}

\section{CONCLUSION AND RECOMMENDATIONS}

The involuntary ghetto is inimical to the American dream.

Equality in the enjoyment of property rights was regarded by the framers of that Amendment [fourteenth] as an essential pre-condition to the realization of other basic civil rights and liberties which the Amendment was intended to guarantee. ${ }^{47}$

All citizens of the United States shall liave the same riglit, in every State and Territory, as is enjoyed by white citizens thereof to inherit, purchase, lease, sell, hold, and convey real and personal property. ${ }^{48}$

It is the public policy of the Umited States, declared by the Congress and the President, and in accord with the declared purposes of the Constitution, that every American family shall have equal opportunity to secure a decent hoine in a good neighborhood. ${ }^{49}$

45 Burks v. Poppy Constr. Co., 57 Cal. 2d 503, 370 P.2d 313, 20 Cal. Rptr. 609 (1962). 46 Letter from Beverly Axelrod (San Francisco attorney involved in the Burks case) to the Author, July 11, 1962.

47 Shelley v. Kraemer, 334 U.S. 1, 10 (1948).

48 REv. STAT. $\$ 1978$ (1875), 42 U.S.C. § 1982 (1958) (derived from $\S 1$ of the Civil Rights Act of 1866). See text accompanying notes 3-4 supra.

49 Report of the United States Commission on Civin Rights 534 (1959). 
Recent socio-economic analyses present measurable evidence of the inferior housing supply, in terms of quality and quantity, available to minorities. ${ }^{50}$ While low income undoubtedly precludes many individuals of various minority groups from exercising free choice in the housing market (assuming free choice is available), others, who are willing and able to meet all financial obligations associated with buying, renting, or leasing a home, are in fact denied this opportunity.

Throughout the country large groups of American citizens-mainly Negroes, but other minorities too-are denied an equal opportunity to choose where they live. Much of the housing market is closed to them for reasons unrelated to their personal worth or ability to pay. New housing, by and large, is available only to whites. And in the restricted market that is open to them, Negroes [and other minority groups] generally must pay more for equivalent housing than do the favored niajority.51

The Cahfornia Advisory Committee of the United States Commission on Civil Rights reported in its survey of 1959 , that in Southern California it was 'almost inpossible' for members of certain minorities to purchase hones in new sub-divisions because of discrimination. 'In rental,' the Committee summarized, 'housing discrimmation is openly practiced and regardless of the ability to pay, minority group members cannot obtain adequate rental facilities.'

In Northern California, according to research presented to the United States Commission on Civil Rights, fewer than 100 non-whites have been able to buy new homes in unsegregated tracts, in a period during which 350,000 new homes were built. A telephone survey in November, 1959, responding to 'For Rent' ads in the San Francisco newspapers, found that of 117 apartments not yet rented, only two were available to Negro applicants, and these were in already ghettoized districts. ${ }^{62}$

Fears associated with a real "free and open market" in housing are largely grounded in myth. ${ }^{53}$ But perhaps the basic anxiety related to entry of a minority individual (especially a nonwhite) into a "closed" neighborhood relates to the "evidence" that property values will fall. An important recent study ${ }^{54}$ has determined:

The major statistical finding of the present study is that during the time period and for the cases studied the entry of nonwhites into previously allwhite neighborhoods was much more often associated with price improvement or stability than with price weakening. ...

so See Grier, Prtvately Developed Interracial Housinc (1960); LaUrenti, Property Values ANd RACE (1960); MCENTIRE, Residence aNd RACE (1960).

514 Report of the United States Concuission on Civin Rights (Housing) 1 (1961).

52 Calif. Comm. for Fair Practices, In a Nutshell, The Proposed Fair Housing Law, 1961.

53 See text accompanying note 54 infra. For an incisive discussion of other myths, see AgraMs, ForbIDDEN NEIGHBORS (1955).

54 LaURenti, Property Values and Race 47-84, 50-53 (1960) ("Control price" refers to all white neighborhoods). 
These conclusions are at variance with the behef that nonwhite entry always provokes a fall in property values. ...

The major variables interacting in the local situations appear to be: (1) strength of whites' desire to move out; (2) strength of nonwhites' desire to move in; (3) willingness of whites to purchase property in racially mixed neighborhoods; (4) housing choice open to whites; (5) housing choices open to nonwhites; (6) absolute and relative purchasing power of nonwhites; (7) absolute and relative levels of house prices; (8) state of general business conditions; (9) longrun trend of values in areas involved; (10) time.

\section{Summary of Findings}

\section{Price behavior in San Francisco, Oakland, and Philadelphia}

A total of 5,417 individual sales prices was collected from 20 formerly all-white neighborhoods which underwent some degree of nonwhite entry during the time of observation. Another 4,495 sales prices were gathered from 19 closely comparable neighborhoods which remained all-white over the same period. Neighborhoods were deliberately selected to give as much diversity as possible in price class, degree of nonwhite occupancy, and other factors.

Studying these comparisons yielded the following principal conclusions on price behavior:

1. In 41 percent of the comparisons, test prices stayed within 5 percent of control prices over the observation period. This is taken as indicating no significant difference in price behavior.

2. In 44 percent of the comparisons test prices ended relatively higher than control prices, by margins ranging from over 5 to 26 percent.

3. In the remaining 15 percent of the comparisons, test prices ended the observation period relatively lower than control prices, by margins rang ing from over 5 to 9 percent.

Two broad conclusions stand out: first, price changes whicl can be connected with the fact of nonwhite entry are not uniform, as often alleged, but diverse. Depending on circumstances, racial change in a neighborhood may be depressing or it may be stimulating to real estate prices and in varying degree. Second, considering all of the evidence, the odds are about four to one that house prices in a neighborhood entered by nonwhites will keep up with or exceed prices in a comparable all-white area. These conclusions are chiefly based on observations of real estate markets in a period of generally rising prices. This period, moreover, was characterized by unusually strong demand for housing, particularly by nonwhites who had been making relatively large gains in personal income. These conditions seem likely to continue into the foreseeable future, and therefore the main findings of the present study may be valid for many neighborhoods certain to experience the entry of nonwhites. 
One might legitimately conclude that the individual white owner or renter practicing discrimination evidences a thinking pattern commonly associated in the semantics of psychiatrists with that of a paranoid. Speaking of the paranoid, Eric Fromm has stated, "For him, reality is based on logical possibility not on probability. ... Reality, for him, is mainly what exists within himself, his own emotions, fears, and desires." "If If paranoidal thinking processes were isolated, perhaps the effect on the community would be rather insignificant. However, entire living environments expressed both in three dimensional-form and concomitant social patterns, the ghetto and white suburbia, have resulted from this distorted view of reality.

If a decent living environment for every individual in California is to become a reality, consideration must be given to the possibility of amending the existing statutes relating to discrimination in housing. Based on this study, the following recommendations appear in order:

1. Although, as described in earlier pages, the Unruh Act extends prohibitions explicit in the Hawkins Act to the private market, given the difficulties posed by the agent-principal relationship and the problems of definition and inherent limitations of the phrase "all business establishments," it is apparent that the Unruh Act will have, at best, a limited effect on discriminatory practices. Furthermore, even with overlapping of the two statutes (Hawkins and Unruh), most nontract, owner occupied, one and two family homes remain exempt, thus effectively limiting the choice of city dwellers. There is no magical fignre beneath which discrimination becomes unimportant. Accordingly:

Discriminatory practices (based on race, religion, or national origin) should be prohibited in the sale, rental, or leasing of all dwellng units and vacant land.

2. Aggrieved parties seeking redress within the framework of both the Hawkins and Unruh Acts presently must resort to the courts. Given the time consuming process, the costs involved, and the uncertainty of the outcome, there is evidence that discriminatees hesitate to initiate a civil suit. $^{56}$ Therefore, complementing the above recommendation relative to coverage, it is proposed that:

Enforcement of both the Hawkins and Unruh Acts along with all other antidiscrimination legislation should be the responsibility of a commission. The commission should be authorized to receive

55 Fromar, May Man PrevaII 19-20 (1961).

56 Indications are that the California attorney general's office may file as party plaintiff in a pending case. Since neither the Hawkins nor the Unruh Acts provides for anyone other than the aggrieved party to initiate a suit, the ability of the attorney general to proceed in this manner is debatable. 
and initiate complaints; to investigate allegations of discrimination; to engage in conciliation attempts; to hold formal hearings; and to seek judicial enforcement of orders. ${ }^{57}$

Although most other personal rights are enforceable only by an aggrieved individual's initiation of a court action in which he must bear the cost and inconvenience of proceedings, the importance of equal treatment to the general welfare gives a state a special interest in vindicating the rights of complainants. ${ }^{58}$

3. In order to protect the rights of the aggrieved party, the commission should have the power to seek an injunction after findings of probable cause, ${ }^{59}$ but before conciliation attempts or a public hearing. ${ }^{60}$

4. The Business and Professions Code ${ }^{61}$ contains provisions which grant regulatory powers over brokers to the Real Estate Commissioner. If a broker violates provisions of the Unruh Act, the Real Estate Commissioner should be empowered to revoke automatically his license to operate a business establishment. ${ }^{62}$ State policy is clear and brokers should not be given "license" to violate it.

57 Administratively, the commission should constitute an omnibus civil rights agency. The present Fair Employment Practices Commission mechanism is available and needs only to be expanded in terms of scope and staff.

While indications are that less than fifty cases have been processed through the court system under the Hawkins and Unruh Acts, during the same comparable time period over 1,722 complaints were filed and processed by the FEPC. The average FEPC case takes about three to four months to process to a solution.

It is clear, therefore, that this proposal would not only better protect minority rights, but the accused property owner would escape the publicity that is attendant upon court proceedings even prior to findings of fact.

There is evidence that the general public, as well as specific minority groups, is not cognizant of the protection available under existing statutes. The commission should be authorized to utilize a variety of educational techmiques in disseminating information to the public.

Finally, review of commission decisions should not be based on a trial de novo concept, but on the weight of the evidence theory. See CAL. CODE CIv. Proc. § 1094.5.

68 See Bamberger \& Lewin, supra note 39 , at 528.

59 Findings that the property owner is seeking to circumvent the antidiscrimination laws by sale, lease, or rental prior to commission action.

60 Compare the Massachusetts statute which reads as follows:

After a determination of probable cause hereunder such commissioner may also

file a petition in equity in the superior court in any county . . . seeking appropriate injunctive relief ... including orders or decrees restraining and enjoining [respondent] ... from selling, renting, or otherwise making unavailable to complainant any housing accommodations with respect to which complaint is made, pending final determination. . . .

Mass. Gen. Laws Ann. ch. 151B, $\S 5$ (Supp. 1961).

61 CaL Bus. \& Prof. Code $\S 10071,10081,10100$.

$62 \mathrm{Mr}$. Justice Douglas, concurring in Garner v. Louisiana, 368 U.S. 157, 184-85 (1961), discussed the application of the fourteenth amendinent to the state licensing power in the following terms:

I do not believe that a State that licenses a business can license it to serve only whites or only blacks or only yellows or only browns. ... The authority to license a business for public use is derived from the public. Negroes are as mnuch a part of 
To date, the existing statutes have pierced only a very small hole in the wall of fear surrounding the ghetto. Passage of new and stronger legislation will not be a panacea. ${ }^{63}$ Economic, social, and cultural handicaps, as well as entrenched custom, will continue to direct minority group individuals and families to select areas. Legislation should not be thought of as an end, in and of itself. Implicit in all the statutes prohibiting discrimination, however, is an image of what can be-a society where freedom to choose a place to live is not limited to whites only.

\section{APPENDIX}

State Statutes Promibiting Discrmmtnation in (A) Public, (B) Urban Renewal or Publicly Assisted, and (C) Private Housino Accommodations

A. PUBLIC HOUSING. Seventeen states and the Virgin Islands have statutes that prohibit discrimination in public housing:

1. Alaska Alaska Sess. Laws 1962, ch. 49 , at 54.

2. California CaL. Heatth \& Safety Code $\$ \$ 35700-41$.

3. Colorado Colo. Rev. Stat. Ann. $\$ \$ 69-7-1$ to -7 (Supp. 1960).

4. Connecticut Conn. Gen. Stat. ANN. \$§ 53-34 to -36 (Supp. 1961).

5. Idaho IdAHo Code ANN. \$§ 18-7301 to -7303 (Supp. 1961).

6. Mlinois IrL. ANN: StaT. ch. 38, \& 13-2(d) (Snnith-Hurd Supp. 1961).

7. Indiana Ind. Ans. Star. \& 10-901 to -902 (Supp. 1962).

8. Massachusetts Mass. Gen. Laws ANn, ch. 121, $\S 26 \mathrm{FF}(\mathrm{e})$ (1958); Mass. GeN. LAws ANN. ch. 151B, §§ 1-6 (Supp. 1961).

9. Michigan Mich. Pub. Acts 1956, No. 182, at 337.

10. Minnesota Monv. Stat. ANN. § 462.481 (Supp. 1961).

11. New Hampshire N.H. REv. Stat. ANn. $\$ \$ 354: 1-: 2,: 4$ (Supp. 1961).

12. New Jersey N.J. REv. Stat. \& 18.25 (Supp. 1961).

13. New York N.Y. Pub. Housng Law $\S \S 156(5), 223$; N.Y. Civ. Rughts Law $\$ \S 18(a)-(e) ;$ N.Y. EXEcuTIVE LAW \$\$ 290-301.

14. Oregon ORE. Rev. StaT. $\$ \$ 659.010-.045,696.300$ (1961).

15. Pennsylvania PA. Stat. ANn. tit. 35, §§ 1661-64 (Supp. 1961).

16. Rhode Island R.I. Gen. Laws ANN. $\$ \$ 11-24-1$ to -4 (1956).

17. Wisconsin Wrs. StaT. ANN. $\$ \$ 66.40-.404$ (1957).

18. Virgin Islands V.I. CoDE ANN. tit. 10, §§ 1-10 (Supp. 1962).

B. URBAN RENEWAI OF PUBLICIX ASSISTED HOUSTNG. Sixteen states and the Virgin Islands have statutes that prohibit discrimination in urban renewal or publicly assisted housing:

1. Alaska Alaska Sess. Laws 1962, ch. 49 , at 54.

2. California CaI. Heattr \& Safety Code $\$ \S 33049-50,35700-41$.

that public as are whites. ... I see no way whereby licenses issued by a State to serve the public can be distinguished from leases of public facihities.

One can close the doors of his lome to anyone he desires. But one who operates an enterprise under a license from the government enjoys a privilege that derives from the people. .... For there is the overriding constitutional requirement that all state power be exercised so as not to deny equal protection to any group.

63 If the housing units available to minorities are to improve both qualitatively and quantitatively, antidiscrimination legislation must be complemented by mechanisms, generic in nature, aimed at either lowering the cost of units or increasing effective purchasing power of low-income individuals. Needs unust be translated into effective demand. 
3. Colorado Coro. Rev. Stat. ANN. §§ 69-7-1 to -7 (Supp. 1960).

4. Connecticut Conn. Gen. Stat. ANN. \$\$ 53-34 to -36 (Supp. 1961).

5. Illinois IrL. ANN. STAT. ch. 671/2, \$§ 63-91, -91.8-.13 (Smith-Hurd 1959).

6. Indiana IND. ANN. STat. §§ 48-8501 to -8503(b) (1950); IND. ANN. STat. §§ 48-8541 to -8543 (b) (Supp. 1962).

7. Massachusetts Mass. Gen. Laws ANn. ch. 151B, §§ 1-6 (Supp. 1961).

8. Minnesota Minn. Stat. Anv. $\S \S 462.481, .525(8), .641$ (Supp. 1961).

9. Montana Mont. Rev. Codes AnN. \$ 11-3917 (Supp. 1961).

10. New Hampshire N.H. REv. STAT. ANN. \$\$ 354:1-2, :4 (Supp. 1961).

11. New Jersey N.J. Rev. Stat. § 18:25 (Supp. 1961).

12. New York N.Y. Crv. RIGHTS Law §§ 18(a)-(e); N.Y. Executrve Law §§ 290-301.

13. Oregon OrE. REv. STAT. $\$ \S 659.010-.045,696.300$ (1961).

14. Pennsylvania PA. Stat. AnN. tit. 35, \$§ 1661-64, 1680.307, 1711 (Supp. 1961); PA. Stat. ANN. tit. 43, §§ 951-63 (Supp. 1961).

15. Washington WASH. REv. CODE $\$ \$ 49.60 .010, .217$ (1957).

16. Wisconsin WIs. Stat. ANN. \$§ 66.405-.425 (1957); WIs. Stat. ANN. $\$ \S 66.431, .431$ (e)2 (Supp. 1962).

17. Virgin Islands V.I. Code ANN. tit. 10, §\$ 1-10 (Supp. 1962).

c. PRIVATE mousing. Ten states and the Virgin Islands have statutes that prohibit discrimination in nonpublicly assisted private housing:

1. Alaska Alaska Sess. Laws 1962, ch. 49, at 54.

2. California CAL. CIv. CoDE \$\$ 51-52.

3. Colorado Colo. Rev. Stat. ANN. \$§ 69-7-1 to -7 (Supp. 1960).

4. Connecticut Conn. Gen. Stat. AnN. §§ 53-34 to -36 (Supp. 1961).

5. Massachusetts Mass. Gen. LAws ANn. ch. 151B, \$\$ 1-6 (1958); Mass. Gen. Laws ANN. ch. 112, § 87AAA(k) (Supp. 1961).

6. Minnesota MenN. StaT. ANn. $\S \S 363.01-.09, .12-.13,507.18$ (Supp. 1961).

7. New Hampshire N.H. REv. Stat. ANN. \$\$ 354:1:2, :4 (Supp. 1961).

8. New Jersey N.J. Rev. Stat. \& 18:25 (Supp. 1961).

9. Oregon ORE. Rev. STAT. $\$ \S 659.010-.045,696.300$ (1961).

10. Pennsylvania PA. STaT. ANN. tit. 43, §\$ 951-63 (Supp. 1961).

11. Virgin Islands V.I. CODE ANN. tit. 10, \$\$ 1-10 (Supp. 1962). 